\title{
Udder Measurements and Their Relationship with Milk Yield in Pelibuey Ewes
}

\author{
Darwin Arcos-Álvarez ${ }^{1,2}$, Jorge Canul-Solís ${ }^{3}$, Ricardo García-Herrera ${ }^{1}$, \\ Luis Sarmiento-Franco $4{ }^{\circledR}$, Ángel Piñeiro-Vazquez ${ }^{2}$, Fernando Casanova-Lugo 5 , \\ Luis O. Tedeschi ${ }^{6}$ (D), Manuel Gonzalez-Ronquillo ${ }^{7}$ (D) and Alfonso Chay-Canul ${ }^{1,2, *(D)}$ \\ 1 División Académica de Ciencias Agropecuarias, Universidad Juárez Autónoma de Tabasco, \\ 86280 Villahermosa, Mexico; darwin.arcos@itconkal.edu.mx (D.A.-Á.); \\ ricardogarciaherrera@hotmail.com (R.G.-H.) \\ 2 Tecnológico Nacional de México/ Instituto Tecnológico de Conkal, 97345 Conkal, Mexico; \\ pineiroiamc@gmail.com \\ 3 Departamento de Posgrado e Investigación, Tecnológico Nacional de México/I. T. Tizimin, 97700 Tizimín, \\ Mexico; jcanul31@gmail.com \\ 4 Facultad de Medicina Veterinaria y Zootecnia, Universidad Autónoma de Yucatán, 97100 Mérida, Mexico; \\ luis.sarmiento@correo.uady.mx \\ 5 Instituto Tecnológico de la Zona Maya, Tecnológico Nacional de México, 77960 Othón P. Blanco, Mexico; \\ fkzanov@gmail.com \\ 6 Department of Animal Science, Texas A\&M University, College Station, TX 77843-2471, USA; \\ luis.tedeschi@tamu.edu \\ 7 Departamento de Nutricion Animal, Facultad de Medicina Veterinaria y Zootecnia, \\ Universidad Autonoma del Estado de Mexico, 50000 Toluca, Mexico; mrg@uaemex.mx \\ * Correspondence: aljuch@hotmail.com
}

Received: 10 February 2020; Accepted: 16 March 2020; Published: 20 March 2020

Simple Summary: The Pelibuey sheep is considered the main maternal breed in the tropical production systems in Mexico. Nonetheless, there are few studies related to milk production and composition. The quantification of milk production in sheep is important because milk is the main source of nutrients for the growth, development and health of lambs. However, in hair sheep breeds, milking is very difficult due to the small size of their teats. Hence, it is important to evaluate indirect methods to estimate the milk yield in Pelibuey ewes to optimize the growth and to develop management strategies for the lambs.

Abstract: The study aimed to evaluate the relationship between udder measurements and milk yield (MY) in dairy Pelibuey ewes. Udder measurements were taken twice a week for eight weeks before (initial) and after (final) milking, including udder depth (UD), udder circumference (UC), udder width (UW), teat length (TL) and teat diameter (TD) in 38 multiparous ewes. Additionally, udder volume (UV) and the difference (VDF) between initial UV (UVi) and final (UVf) was calculated as $\mathrm{VDF}=\mathrm{UVi}-\mathrm{UVf}$. The MY varied from $0.10 \mathrm{~kg} / \mathrm{d}$ to $1.04 \mathrm{~kg} / \mathrm{d}$, with a mean of $0.39 \mathrm{~kg} / \mathrm{d}, \pm 0.18 \mathrm{~kg} / \mathrm{d}$. Initial UC (UCi) ranged from $25.80 \mathrm{~cm}$ to $53.30 \mathrm{~cm}$, and VDF varied from $1 \mathrm{~cm}^{3}$ to $2418 \mathrm{~cm}^{3}$. The TL and TD were not correlated with MY $(p>0.05)$, while UCi, UVi and VDF were positively correlated with MY $(p<0.0001 ; r=$ from 0.66 to 0.74$)$. For the prediction of MY, the obtained equations had an $r^{2}$ ranging from 0.54 to 0.63 . The UCi, UDf, UWi and UWf were included in these models $(p<0.05)$. It is concluded that there was an acceptable correlation $(r=0.60)$ between the measurements of the udder, the volume of the udder and the daily milk yield in Pelibuey sheep. When direct measurements of milk production cannot be performed in practice, the measurement of udders and their volume could be a viable alternative to estimate milk yield production as an indirect method. 
Keywords: udder measurements; milk yield; hair sheep; mathematical models

\section{Introduction}

In the tropical regions of Latin America, sheep production systems are characterised by the use of animal genetic resources of native creole breeds, mainly hair sheep breeds [1]. In Mexico, the most common sheep breeds used in order of importance are the Pelibuey, Black Belly, Katahdin and Dorper breeds [1].

In the last decade, Pelibuey sheep have been the main maternal breed used for sheep breeding in the tropics of Mexico [2]. One of the first studies to determine the milk production and composition of milk from Pelibuey ewes was carried out by Castellanos and Valencia [3]. However, to date, few studies have evaluated these aspects in Pelibuey ewes and their crosses with Katahdin under tropical conditions in Mexico [4-6].

The quantification of milk production in sheep is important because milk is the main source of nutrients for the growth, development and health of lambs. If milk production is insufficient, the growth of lambs could be hampered [6-8]. For this reason, it is necessary to know the milk production in order to propose, if necessary, economically viable and profitable intervention strategies to increase milk production.

Many nutritional models use milk yield to determine the proper formulation of supplements and rations for ruminant animals based on their energy and nutrient needs $[9,10]$. However, in Pelibuey ewes, Ampueda and Combellas [11] reported that it was very difficult to milk the animals in order to measure the amount of milk produced, especially due to the small size of their teats. Although some studies have estimated milk production in hair breeds using direct and indirect methods, such as manual milking, mechanical milking and the double lamb weighing technique [5], it is important to evaluate other indirect methods that are easy to carry out. Among these indirect methods, udder measurements and the weight gain of lambs has been evaluated in addition to more sophisticated and expensive techniques, such as the dilution of isotopes $[5,6,12-14]$. The need to correctly assess milk yield is important, but there is a chronic lack of information $[15,16]$ and a lack of dissemination of available and accurate methods [10].

The present study was based on udder measurements to determine udder volume by means of mathematical formulas, which could be a useful tool for predicting milk production. This method is viable, practical and low in cost, unlike many other techniques $[6,12,17]$. Additionally, good correlations were previously found between the size of teats and udders and the production of milk in different breeds of sheep [12,16-18]. Because no studies have used udder measurements to predict milk yield in hair sheep, the objective of the present study was to evaluate the relationship between udder measurements and milk production in Pelibuey ewes.

\section{Material and Methods}

\subsection{Experimental Site, Animals and Collection of Udder Measurements}

The animals were treated in accordance with guidelines and regulations for animal experimentation of the División Académica de Ciencias Agropecuarias, Universidad Juárez Autónoma de Tabasco. The present study was approved by review committee approval number: PFI: UJAT-DACA-2015-IA-02.

The experiment was carried out at the Centro de Integración Ovina del Sureste (CIOS) located at $17^{\circ} 78^{\prime \prime} \mathrm{N}, 92^{\circ} 96^{\prime \prime} \mathrm{W}, 10 \mathrm{~m}$ above sea level and $29 \mathrm{~km}$ from the Villahermosa-Teapa highway in Tabasco, Mexico. Pelibuey ewes of differing body condition scores (BCS) on a scale of $1-5$ were selected from a commercial farm, with a score of 1 indicating very thin and 5 obese [19]. Thirty-eight recently lambed (5-10 days), clinically healthy Pelibuey ewes (aged $2-3$ years) with single $(n=33)$ and twin 
lambing $(\mathrm{n}=5)$ were considered in the present study, with $36.34 \mathrm{~kg} \pm 4.90 \mathrm{~kg}$ average body weight (BW) and an average $\mathrm{BC}$ of $1.5 \pm 0.50$.

The ewes and their lambs were confined in raised slatted-floor cages in roofed buildings without walls. The food supply consisted of star grass hay (Cynodon nlemfuensis), ground corn, soybean meal, sugarcane molasses and minerals, with an estimated metabolisable energy of $12 \mathrm{MJ} / \mathrm{kg}$ DM and $15 \%$ crude protein [20]. Throughout the experiment the diet was offered ad libitum, with feeding levels designed to ensure a refusal margin of $10 \%$ each day. The diet was formulated to meet the requirements of dairy ewes with a mean BW of $45 \mathrm{~kg}$ and a mean milk yield of $1.74 \mathrm{~kg} / \mathrm{d}$. The crude protein (CP) and fat contents were $4.5 \%$ and $7.0 \%$, respectively, according to the AFRC [20] equations. The objective was to maintain constant BWs and BCSs of ewes throughout the whole experimental period.

The daily milk yield (DMY, $\mathrm{kg}$ ) of ewes was determined by hand milking from the second week after parturition until weaning of the lambs at 56 days. The lambs were separated daily from their dam at 19:00 h. During this period, the lambs had free access to feed (18\% CP, $12 \mathrm{MJ} \mathrm{ME} / \mathrm{kg} \mathrm{DM})$. After $12 \mathrm{~h}$ of separation, the ewes were milked after being injected IM with $3 \mathrm{IU}$ of oxytocin. Before milking was performed, the teats of the animals were disinfected using an iodine solution and, after about $30 \mathrm{~s}$, the teats were dried with paper towels.

Before (i) and after (f) milking, the following udder measurements $(\mathrm{cm})$ were recorded for each ewe as described by Emediato et al. [17] and Merkhan and Alkass [21]: Udder depth (UD), udder circumference (UC), udder width (UW), teat length (TL) and teat diameter (TD). For the measurements, a flexible fibreglass tape (Truper®, Truper S.A. de C.V., San Lorenzo, Mexico) and a digital calliper (Truper®, Truper S.A. de C.V., San Lorenzo, Mexico) were used. All measurements were taken twice a week (347 independent measurements). The udder volume (UV) was calculated according to the equation described by Izadifard and Zamiri [22]. Additionally, the difference (VDF) between initial UV (UVi) and the final UV (UVf) was calculated as VDF $=\mathrm{UVi}-\mathrm{UVf}$.

$$
\begin{gathered}
R=\mathrm{CP} / 2 \times \pi \\
\mathrm{UV}=\pi \times R^{2} \times \mathrm{UD}
\end{gathered}
$$

where $R=$ the radius $(\mathrm{cm}), \mathrm{CP}=$ the circumference perimeter $(\mathrm{cm}), \pi=3.142, \mathrm{UV}=$ udder volume $\left(\mathrm{cm}^{3}\right)$ and $\mathrm{UD}=$ udder depth $(\mathrm{cm})$.

\subsection{Statistical Analyses}

The descriptive statistical analysis was performed using the PROC MEANS procedure of SAS [23]. Correlation coefficients among variables were estimated using the PROC CORR procedure of SAS [23]. Regressions were developed using the PROC REG procedure of SAS [23]. The STEPWISE option and Mallow's Cp were used in the SELECTION statement to select the variables included in the model. Data points were removed if their studentised residual was outside the range of -2.5 to 2.5 . The effect of litter size was included in the statistical analyses as a covariate.

According to Tedeschi [24], several statistics have been used to assess the predictability of the equations, including the coefficients of determination $\left(\mathrm{r}^{2}\right)$, mean square error (MSE), standard deviation (SD), mean square error of prediction (MSEP) and root of the MSEP (RMSEP), in order to account for the difference between predicted values and true values. The mean bias (MB), as described by Cochran and Cox [25], was used as a representation of the average inaccuracy of the model. The modelling efficiency factor (MEF), which represents the proportion of variation explained by the line $Y=X$, was used as an indicator of goodness of fit [26,27]. The coefficient of model determination (CD) was used to assess variance in the predicted data. The bias correction factor $(\mathrm{Cb})$, a component of the concordance correlation coefficient (CCC) [28], was used as an indicator of deviation from the identity line, and the CCCs were also used as a reproducibility index to account for accuracy and precision. High accuracy and precision were assumed when the coefficients were $>0.80$, and low accuracy and precision were 
assumed when the coefficients were $<0.50$. Finally, all calculations were obtained using the Model Evaluation System [24].

\section{Results}

Descriptive statistics for udder measurements and milk yield are presented in Table 1. A large variation in milk yield $(0.100-1.04 \mathrm{~kg} / \mathrm{d})$ was observed, with a mean of $0.39 \mathrm{~kg} / \mathrm{d} \pm 0.18 \mathrm{~kg} / \mathrm{d}$. The UCi and the VDF also widely ranged from $25.80 \mathrm{~cm}$ to $53.30 \mathrm{~cm}$ and from $1.030 \mathrm{~cm}^{3}$ to $2418 \mathrm{~cm}^{3}$, respectively.

Table 1. Descriptive statistics for udder measurements and milk yield in Pelibuey ewes.

\begin{tabular}{lllll}
\hline Variable & \multicolumn{1}{c}{ Description } & \multicolumn{1}{c}{ Mean \pm SD } & \multicolumn{1}{c}{ Maximum } & Minimum \\
\hline MY & Daily milk yield $(\mathrm{kg})$ & $0.39 \pm 0.18$ & 1.04 & 0.10 \\
UCi & Initial udder circumference $(\mathrm{cm})$ & $39.61 \pm 4.99$ & 53.30 & 25.80 \\
UCf & Final udder circumference $(\mathrm{cm})$ & $33.38 \pm 4.59$ & 45.0 & 24.30 \\
UDi & Initial udder height $(\mathrm{cm})$ & $13.91 \pm 2.51$ & 20.30 & 5.00 \\
UDf & Final udder height $(\mathrm{cm})$ & $12.51 \pm 2.23$ & 20.0 & 5.70 \\
UWi & Initial udder width $(\mathrm{cm})$ & $11.68 \pm 1.55$ & 15.5 & 7.10 \\
UWf & Final udder width $(\mathrm{cm})$ & $9.53 \pm 1.79$ & 15.2 & 1.30 \\
TDi & Initial diameter of the teat $(\mathrm{cm})$ & $1.58 \pm 0.62$ & 2.90 & 1.00 \\
TDf & Final diameter of the teat $(\mathrm{cm})$ & $1.49 \pm 0.51$ & 2.70 & 1.00 \\
TLi & Initial length of the teat $(\mathrm{cm})$ & $2.64 \pm 1.41$ & 4.50 & 1.20 \\
TLf & Final length of the teat $(\mathrm{cm})$ & $2.51 \pm 0.37$ & 3.70 & 1.20 \\
UVi & Initial udder volume $\left(\mathrm{cm}^{3}\right)$ & $1790 \pm 652.58$ & 4271 & 664.47 \\
UVf & Final udder volume $\left(\mathrm{cm}^{3}\right)$ & $1137 \pm 384.81$ & 2862 & 458.84 \\
VDF & Difference between $\mathrm{UV}\left(\mathrm{UVi}-\mathrm{UVf}, \mathrm{cm}^{3}\right)$ & $652.42 \pm 446.88$ & 2418 & 1.03 \\
\hline
\end{tabular}

The suffix initial and final indicate that the measures were taken before (i) and after (f) every milking.

The UWf, TDi, TDf, TLi and TLf were not correlated with milk yield $(p>0.05)$. A moderate correlation was found between milk yield and UCi $(r=0.66)$ and between milk yield and the UDi $(r=0.47)$ and UWi $(r=0.49)$ (Table 2$)$. A positive correlation $(p<0.0001)$ was found between milk yield with UVi $(r=0.71)$ and VDF $(r=0.74)$. For the prediction of milk yield, the obtained equations had an $r^{2}$ that ranged from 0.54 to 0.63 (Table 3). The UCi, UDf, UWi and UWf were included in these models $(p<0.05)$.

Table 2. Correlation coefficients among measured variables for udder measurements and mean daily milk yield in Pelibuey ewes.

\begin{tabular}{|c|c|c|c|c|c|c|c|c|c|c|c|c|c|}
\hline & UCf & UDi & UDf & UWi & UWf & TDi & TDf & TLi & TLf & UVi & UVf & VDF & MY \\
\hline $\mathrm{UCi}$ & $0.68^{* * *}$ & $0.31 * * *$ & $0.24 *$ & $0.61^{* * *}$ & $0.37^{* * *}$ & $-0.05^{\mathrm{ns}}$ & $-0.06^{\mathrm{ns}}$ & $0.05^{\mathrm{ns}}$ & $0.06^{\mathrm{ns}}$ & $0.85^{* * *}$ & $0.69^{* * *}$ & $0.66^{* * *}$ & $0.66^{* * *}$ \\
\hline UCf & 1.00 & $0.18^{\mathrm{ns}}$ & $0.12^{\mathrm{ns}}$ & $0.38^{* * *}$ & $0.37^{* * *}$ & $-0.06^{* * *}$ & $0.02^{\mathrm{ns}}$ & $-0.02^{\mathrm{ns}}$ & $0.04^{\mathrm{ns}}$ & $0.56^{* * *}$ & $0.79^{* * *}$ & $0.14^{* * *}$ & $0.24^{* * *}$ \\
\hline UDi & & 1.00 & $0.63^{* * *}$ & $0.16^{\mathrm{ns}}$ & $0.06^{\mathrm{ns}}$ & $-0.030^{\mathrm{ns}}$ & $0.003^{\text {ns }}$ & $0.08^{\mathrm{ns}}$ & $0.14^{\mathrm{ns}}$ & $0.72^{* * *}$ & $0.48^{* * *}$ & $0.65^{* * *}$ & $0.47^{* * *}$ \\
\hline IDf & & & 1.00 & $0.15^{\mathrm{ns}}$ & $0.07^{\mathrm{ns}}$ & $-0.033^{\mathrm{ns}}$ & $-0.03^{\text {ns }}$ & $0.06^{\mathrm{ns}}$ & $0.14^{\mathrm{ns}}$ & $0.49^{* * *}$ & $0.65^{* * *}$ & $0.16^{\mathrm{ns}}$ & $0.27^{* * *}$ \\
\hline UWi & & & & 1.00 & $0.46^{\text {****}}$ & $0.07^{\mathrm{ns}}$ & $0.04^{\mathrm{ns}}$ & $0.08^{\mathrm{ns}}$ & $0.016^{\mathrm{ns}}$ & $0.51^{* * *}$ & $0.41^{* * *}$ & $0.39^{* * *}$ & $0.49^{* * *}$ \\
\hline UWf & & & & & 1.00 & $0.005^{\mathrm{ns}}$ & $0.05^{\mathrm{ns}}$ & $0.01^{\mathrm{ns}}$ & $0.05^{\mathrm{ns}}$ & $0.31^{* * *}$ & $0.37^{* * *}$ & $0.13^{\text {ns }}$ & $0.15^{\mathrm{ns}}$ \\
\hline TDi & & & & & & 1.00 & $0.08^{\mathrm{ns}}$ & $0.07^{\mathrm{ns}}$ & $0.18^{*}$ & $-0.03^{\mathrm{ns}}$ & $-0.05^{\mathrm{ns}}$ & $-0.007^{\mathrm{ns}}$ & $0.003^{\text {ns }}$ \\
\hline TDf & & & & & & & 1.00 & $0.01^{\mathrm{ns}}$ & $0.24^{\text {*** }}$ & $-0.03^{\text {ns }}$ & $0.006^{\mathrm{ns}}$ & $-0.05^{\mathrm{ns}}$ & $-0.05^{\mathrm{ns}}$ \\
\hline $\mathrm{TLi}$ & & & & & & & & 1.00 & $0.19^{\text {ns }}$ & $0.07^{\mathrm{ns}}$ & $0.009^{\text {ns }}$ & $0.09^{\text {ns }}$ & $0.12^{\text {ns }}$ \\
\hline TLf & & & & & & & & & 1.00 & $0.11^{\text {ns }}$ & $0.10^{\text {ns }}$ & $0.07^{\mathrm{ns}}$ & $0.11^{\text {ns }}$ \\
\hline UVi & & & & & & & & & & 1.00 & $0.74^{* * *}$ & $0.81^{* * *}$ & $0.71^{* * *}$ \\
\hline UVf & & & & & & & & & & & 1.00 & $0.22^{* * *}$ & $0.35^{* * *}$ \\
\hline VDF & & & & & & & & & & & & 1.00 & $0.74^{* * *}$ \\
\hline
\end{tabular}

${ }^{*} p<0.05 ;{ }^{* * *} p<0.0001$; NS: Not significant, $p>0.05$; MY: Daily milk yield; UCi: Initial udder circumference; UCf: Final udder circumference; Udi: Initial udder height; UDf: Final udder height; UWi: Initial udder width; UWf: Final udder width; TDi: Initial diameter of the teat; TDf: Final diameter of the teat; TLi: Initial length of the teat; TLf: Final length of the teat; UVi: Initial udder volume; UV: Final udder volume; VDF: Difference between UV $\left(\mathrm{UVi}-\mathrm{UVf}, \mathrm{cm}^{3}\right)$. 
Table 3. Regression equations for predicting milk yield (MY, kg/d) according to udder measurements in Pelibuey ewes.

\begin{tabular}{|c|c|c|c|c|c|c|}
\hline \# & Equation & $\mathbf{n}$ & MSE & RMSE & $r^{2}$ & $p$ \\
\hline 3 & $\mathrm{MY}(\mathrm{kg})=0.194\left( \pm 0.012^{* * *}\right)+0.00031\left( \pm 0.000015^{* * *}\right) \times \mathrm{UDf}$ & 347 & 0.016 & 0.126 & 0.54 & 0.0001 \\
\hline 4 & $\begin{array}{c}\mathrm{MY}(\mathrm{kg})=-0.204\left( \pm 0.065^{*}\right)+0.011\left( \pm 0.001^{* * *}\right) \times \mathrm{UCi}+0.0002( \pm \\
\left.0.00001^{* * *}\right) \times \mathrm{VDF}\end{array}$ & 347 & 0.014 & 0.118 & 0.60 & 0.0001 \\
\hline 5 & $\begin{aligned} \mathrm{MY}(\mathrm{kg})= & -0.276\left( \pm 0.063^{* * *}\right)+0.008\left( \pm 0.001^{* * *}\right) \times \mathrm{UCi}+0.017( \pm \\
& \left.0.005^{*}\right) \times \mathrm{UWi}+0.0002\left( \pm 0.00001^{* * *}\right) \times \mathrm{VDF}\end{aligned}$ & 347 & 0.013 & 0.114 & 0.61 & 0.0001 \\
\hline 6 & $\begin{array}{c}\mathrm{MY}(\mathrm{kg})=-0.356\left( \pm 0.066^{* * *}\right)+0.006\left( \pm 0.001^{*}\right) \times \mathrm{UCi}+0.009( \pm \\
\left.0.002^{*}\right) \times \mathrm{UDf}+0.017\left( \pm 0.005^{*}\right) \times \mathrm{UWi}+0.0002\left( \pm 0.00001^{* * *}\right) \times \mathrm{VDF} \\
\mathrm{MY}(\mathrm{kg})=-0.34\left( \pm 0.66^{* * *}\right)+0.007\left( \pm 0.001^{* * *}\right) \times \mathrm{UCi}+0.009( \pm\end{array}$ & 347 & 0.013 & 0.114 & 0.62 & 0.0001 \\
\hline 7 & $\begin{array}{c}\left.0.002^{*}\right) \times \mathrm{UDf}+0.02\left( \pm 0.005^{* * *}\right) \times \mathrm{UWi}-0.009\left( \pm 0.004^{*}\right) \times \mathrm{UWf}+ \\
0.0002\left( \pm 0.00001^{* * *}\right) \times \mathrm{VDF}\end{array}$ & 347 & 0.013 & 0.114 & 0.63 & 0.0001 \\
\hline
\end{tabular}

${ }^{*} p<0.05 ; * * * p<0.0001$; MSE: Mean square error; RMSE: Root mean square error; $r^{2}$ : Coefficient of determination; MY: Daily milk yield; UCi: Initial udder circumference; UDf: Final udder height; UWi: Initial udder width; UWf: Final udder width; VDF: Difference between UV (UVi - UVf, $\left.\mathrm{cm}^{3}\right)$.

The predictive equations obtained in the current study were moderately precise $\left(r^{2}=0.55\right.$ to 0.63$)$ but highly accurate $(\mathrm{Cb}=0.85$ to 0.97$)$, with a reproducibility index ranging from 0.68 to 0.78 (Table 4 ). The MEF indicated a moderate efficiency of prediction (from 0.47 to 0.63 ). The CD ranged from 1.56 to 1.89 , indicating high variability in the predicted data (Table 4), whereas the partition of the \% MSEP indicated that the mean bias fluctuated from 0.001 to 28.50 and that the systematic bias varied from $0.01 \%$ to $1.58 \%$ (Table 4 ).

Table 4. Mean and descriptive statistics of the accuracy and precision of the equations for predicting milk yield based on udder measurements and udder volume versus the observed milk yield in Pelibuey ewes.

\begin{tabular}{|c|c|c|c|c|c|c|}
\hline Variable $^{1}$ & Obs & (Equation (3)) & (Equation (4)) & (Equation (5)) & (Equation (6)) & (Equation (7)) \\
\hline SD & 0.188 & 0.138 & 0.132 & 0.134 & 0.132 & 0.150 \\
\hline Minimum & 0.095 & 0.194 & 0.090 & 0.068 & 0.036 & 0.047 \\
\hline$r^{2}$ & - & 0.55 & 0.59 & 0.61 & 0.62 & 0.63 \\
\hline $\mathrm{CCC}$ & - & 0.71 & 0.71 & 0.73 & 0.68 & 0.78 \\
\hline MEF & & 0.55 & 0.56 & 0.58 & 0.47 & 0.63 \\
\hline $\mathrm{CD}$ & & 1.86 & 1.89 & 1.88 & 1.56 & 1.56 \\
\hline \multicolumn{7}{|l|}{ Regression analysis } \\
\hline \multicolumn{7}{|l|}{ Intercept $\left(\beta_{0}\right)$} \\
\hline Estimate & - & -0.003 & -0.002 & -0.009 & 0.031 & 0.009 \\
\hline SE & - & 0.020 & 0.018 & 0.018 & 0.016 & 0.017 \\
\hline SE & - & 0.049 & 0.048 & 0.046 & 0.047 & 0.040 \\
\hline$p$ value $\left(\beta_{1}=1\right)$ & - & 0.85 & 0.04 & 0.04 & 0.01 & 0.89 \\
\hline \multicolumn{7}{|l|}{ MSEP source, \% } \\
\hline \multicolumn{7}{|l|}{ MSEP } \\
\hline Mean bias & - & 0.001 & 7.58 & 4.96 & 28.51 & 0.45 \\
\hline Systematic bias & - & 0.010 & 1.15 & 1.16 & 1.58 & 0.01 \\
\hline Random error & - & 99.98 & 91.27 & 93.89 & 69.91 & 99.54 \\
\hline \multicolumn{7}{|l|}{ Root MSEP } \\
\hline Estimate & - & 0.13 & 0.12 & 0.12 & 0.14 & 0.11 \\
\hline$\%$ of the mean & - & 31.93 & 34.47 & 32.66 & 42.57 & 29.42 \\
\hline
\end{tabular}

${ }^{1}$ Obs: Observed evaluation data set; SD: standard deviation; CCC: Concordance correlation coefficient; Cb: Bias correction factor; MEF: Modelling efficiency; CD: Coefficient of model determination; MSEP: Mean square error of the prediction; (Equations (3)-(7)): in the Table 3. 


\section{Discussion}

In the present study, the viability of using udder measurements to predict milk production in Pelibuey ewes was evaluated. The literature contains few studies reporting milk production in hair sheep breeds, such as the Pelibuey and their crosses [4-6], in which milk yields around 1.1-1.74 kg/d have been reported. Although some information is available on milk yield in this breed, no reliable non-nvasive tools have been validated to predict milk yield in this breed. The udder measurements have been used to estimate milk production in dairy ewes of several sheep breeds $[12,17,18,28,29]$. However, this is the first study that has reported the use of udder measurements to predict milk yield in Pelibuey ewes.

Emediato et al. [17] reported positive correlations in Bergamasca ewes between daily milk yield and udder depth, circumference and width ( $r=0.74,0.75$ and 0.62, respectively). Ayadi et al. [18] evaluated mammary morphology and milk production in Sicilia-Sarde dairy sheep. Daily milk yield was positively and significantly correlated with UV and UD. Similar to our results, these authors did not observe significant correlations among daily milk yield and diameter or length of teats. Likewise, Sezenler et al. [30] found positive and significant correlations between DMY and udder circumference and udder width, indicating that udder measurements could serve as a predictor of milk production. Likewise, the evaluations carried out by Angeles et al. [29] reported an association between different morphological traits of body and udders of Spanish Assaf sheep. In particular, udder traits such as depth $\left(r^{2}=0.47\right)$ and length $\left(r^{2}=0.25\right)$ were the most correlated with milk production. These studies are in agreement with the findings of Iñiguez et al. [12] for Awassi sheep and their crosses, where total milk production and total protein, fat and nonfat solids were positively correlated ( $r=0.36$ to 0.76 ) with udder circumference and udder width, which is similar to our results, where we found a positive moderate correlation among UWi, UCi and MY ( $r=0.49$ to 0.66 , respectively).

Positive relationships between udder measurements and milk production have been reported in other species. In dromedary camels, Musaad et al. [31] reported that udder depth, udder circumference and distance between teats were positively correlated with milk production and were significantly affected $(p \leq 0.05)$ by the lactation stage. Merkhan and Alkass [21] evaluated Black and Meriz goats and found that milk production was correlated with udder circumference and udder length $(p<0.01)$ in both breeds. In Saanen goats, Linzell [32] reported a high correlation $(r=0.87)$ between udder volume and milk production. Capote et al. [33] also evaluated the correlations between udder morphology and milk yield in Tinerfen dairy goats and obtained a positive correlation $(r=0.79)$ between udder volume and milk production. On the contrary, in Sicilia-Sarden sheep, Ayadi et al. [18] did not find any relationship between the distance between teats $(p>0.05)$ and milk production.

Udder morphology measurements, their relationships with milk production traits and their usefulness for genetic improvement has been studied in different sheep breeds [12,16]. Among these measurements, udder circumference and teat width has been shown to be significantly correlated with total milk yield and are considered good predictors of performance in several sheep breeds [12]. In addition, Capote et al. [34] indicated a greater importance on the balance between the horizontal and vertical diameters of udder compared with length parameters. Other authors [12,16,18,32-34] have suggested that the predictive capacity of udder measurements have important practical implications for breeding programmes to increase resilience to mastitis in the population [35]. In addition, Milerski et al. [36] reported that the linear scores for udder depth, cistern depth, teat position and teat size would permit prediction of future correlated responses in milk-oriented selection schemes in the Tsigai, Improved Walachian and Lacaune breeds. Ewes with ideal udder sizes (MY = 1.04, $\mathrm{UCi}=53.30, \mathrm{UDf}=20, \mathrm{UWi}=15.5, \mathrm{UWf}=15.2, \mathrm{VDF}=2418$ ) could be selected to improve milk production. Our analysis was highly accurate $(\mathrm{Cb}>0.852$ and RMSEP $>29 \%)$ in predicting milk yield according to the selected udder measurements, but the precision $\left(\mathrm{r}^{2}<0.632\right)$ was systematically low, resulting in under prediction $(C D<1.897)$ across equations. The variation in milk yield may be largely explained by environmental effects [6] or genotype [6,15,37]. Although the previous studies indicated that ewes rearing twin lambs had higher daily milk yields [6,38], because of low prolificacy 
in the present study (1.13), the effect of litter size could not be determined due to insufficient statistical power. Likewise, the animals used in this study were very thin, $1.5 \pm 0.50$ points of BCS (on a scale of 1 to 5). However, this BCS is characteristic of tropical sheep-production systems based on grazing in the dry season [1]. Although we obtained a moderate and positive correlations estimates among udder measurements and milk yield in Pelibuey ewes in the current study, more work is required to explore the other factors that affect milk production (level of feeding, animal health, litter size, BCS, body mass index, genetics) in hair sheep ewes raised in tropical production systems. Therefore, for predictive purposes, these factors could also be considered to achieve precise and accurate prediction of milk yield.

\section{Conclusions}

The present study obtained moderate and positive correlations estimates among udder measurements, udder volume and daily milk yield in Pelibuey ewes. The udder measurements and its volume could be a useful tool to predict milk yield.

Author Contributions: Conceptualization and methodology, D.A.-Á., A.C.-C., R.G.-H., Á.P.-V. and L.S.-F.; investigation, D.A.-Á., A.C.-C., R.G.-H., J.C.-S. and Á.P.-V.; data curation and analysis, D.A.-Á., A.C.-C., F.C.-L. and L.O.T.; writing—original draft preparation, D.A.-Á., A.C.-C., R.G.-H., Á.P.-V. and M.G.-R.; funding acquisition, J.C.-S. and A.C.-C. All authors have read and agreed to the published version of the manuscript. All the authors have been involved in developing, writing, and commenting on the manuscript.

Funding: This research received no external funding

Acknowledgments: The authors are grateful for the assistance of engineer Walter Lanz Villegas, who granted access to the facilities of the Centro de Integracion Ovina del Sureste (CIOS). We also thank J. Mezo-Solis, E. Bautista-Diaz, R. Espinosa-Mendoza and R. I. Narváez-Ballesteros for their technical assistance.

Conflicts of Interest: The authors declare that they have no conflicts of interest.

\section{References}

1. Chay-Canul, A.J.; Magaña-Monforte, J.G.; Chizzotti, M.L.; Piñeiro-Vázquez, Á.T.; Canul-Solís, J.R.; Ayala-Burgos, A.J.; Ku-Vera, J.C.; Tedeschi, L.O. Energy requirements of hair sheep in the tropical regions of Latin America. Review. Rev. Mex. Cienc. Pecu. 2016, 7, 105-125.

2. Bautista-Díaz, E.; Salazar-Cuytun, R.; Chay-Canul, A.J.; Garcia Herrera, R.A.; Piñeiro-Vázquez, Á.T.; Magaña-Monforte, J.G.; Tedeschi, L.O.; Cruz-Hernández, A.; Gómez-Vázquez, A. Determination of carcass traits in Pelibuey ewes using biometric measurements. Small Rumin. Res. 2017, 147, 115-119. [CrossRef]

3. Castellanos, R.A.; Valencia, Z.M. Estudio cuantitativo y cualitativo de la producción láctea de la borrega Pelibuey. Prod. Anim. Trop. 1982, 7, 245-253.

4. Espinoza-Hernández, J.C.; Ayala-Burgos, A.J.; Aguilar-Pérez, C.F.; Magaña-Monforte, J.G.; Ku-Vera, J.G. Milk yield and composition, and efficiency of utilization of metabolisable energy for lactation by Pelibuey ewes. In Energy and Protein Metabolism and Nutrition in Sustainable Animal Production; Oltjen, J.W., Kebreab, E., Lapierre, H., Eds.; Wageningen Academic Publishers: Wageningen, The Netherlands, 2013; Volume 134, pp. 123-124.

5. Peniche-Gonzalez, I.; Sarmiento-Franco, L.; Santos-Ricalde, R. Estimation of milk production in hair ewes by two methods of measurement. Rev. MVZ Córdoba 2015, 20, 4629-4635. [CrossRef]

6. Chay-Canul, A.J.; Aguilar-Urquizo, E.; Parra-Bracamonte, G.M.; Piñeiro-Vazquez, Á.T.; Sanginés-García, J.R.; Magaña-Monforte, J.G.; García-Herrera, R.A.; López-Villalobos, N. Ewe and lamb pre-weaning performance of Pelibuey and Katahdin hair sheep breeds under humid tropical conditions. Ital. J. Anim. Sci. 2019, 18, 850-857. [CrossRef]

7. Miguel-Romera, J.A.; Calvo-Ruiz, J.L.; Ciria-Ciria, J.; Asenjo-Martín, B. Effect of feeding systems on live-weight, reproductive performance, milk yield and composition, and the growth of lambs in native Spanish Ojalada sheep. Span. J. Agric. Res. 2011, 9, 769-780. [CrossRef]

8. Ayadi, M.; Matar, A.M.; Aljumaah, R.S.; Alshaikh, M.A.; Abouheif, M.A. Factors affecting milk yield, composition and udder health of Najdi ewes. Asian. J. Anim. Veter. Adv. 2014, 6, 28-33. [CrossRef] 
9. Tedeschi, L.O.; Cannas, A.; Fox, D.G. A nutrition mathematical model to account for dietary supply and requirements of energy and nutrients for domesticated small ruminants: The development and evaluation of the Small Ruminant Nutrition System. Small Rumin. Res. 2010, 89, 174-184. [CrossRef]

10. Tedeschi, L.O.; Fox, D.G. The Ruminant Nutrition System: An Applied Model for Predicting Nutrient Requirements and Feed Utilization in Ruminants, 2nd ed.; XanEdu Publishing Inc.: Acton, MA, USA, 2017.

11. Ampueda, J.; Combellas, J. Estimación de la producción de leche en ovejas West African. Prod. Latin. 2000, 25, 533-535.

12. Iñiguez, L.; Hilali, M.; Thomas, D.L.; Jesry, G. Udder measurements and milk production in two Awassi sheep genotypes and their crosses. J. Dairy Sci. 2009, 92, 4613-4620. [CrossRef] [PubMed]

13. Van der Linden, D.S.; Lopez-Villalobos, N.; Kenyon, P.R.; Thorstensen, E.; Jenkinson, C.M.C.; Peterson, S.W.; Blair, H.T. Comparison of four techniques to estimate milk production in singleton-rearing non-dairy ewes. Small Rumin. Res. 2010, 90, 18-26. [CrossRef]

14. Ochepo, G.O.; Ayoade, J.A.; Attah, S.; Adenkola, A.Y. Effect of Breed and Method of Milking on Yield and Composition of Sheep Milk. Sch. J. Agric. Sci. 2015, 5, 232-235.

15. Ferro, M.M.; Tedeschi, L.O.; Atzori, A.S. The comparison of the lactation and milk yield and composition of selected breeds of sheep and goats. Transl. Anim. Sci. 2017, 1, 498-506. [CrossRef]

16. Pourlis, A. Ovine mammary morphology and associations with milk production, milkability and animal selection. Small Rumin. Res. 2020, 184, 106109. [CrossRef]

17. Emediato, R.M.S.; Siqueira, E.R.; Stradiotto, M.M.; Maestá, S.A.; Fernandes, S. Relationship between udder measurements and milk yield in Bergamasca ewes in Brazil. Small. Rumin. Res. 2008, 75, 232-235. [CrossRef]

18. Ayadi, M.; Such, X.; Ezzehizi, N.; Zouari, M.; Najar, T.; Ben M’Rad, M.; Casals, R. Relationship between mammary morphology traits and milk yield of Sicilo-Sarde dairy sheep in Tunisia. Small Rumin. Res. 2011, 96, 41-45. [CrossRef]

19. Russel, A.J.F.; Doney, J.M.; Gunn, R.G. Subjective assessment of body fat in live sheep. J. Agric. Sci. 1969, 72, 451-454. [CrossRef]

20. Agricultural and Food Research Council (Great Britain). Energy and Protein Requirements of Ruminants: An advisory manual; CAB International: Wallingford, UK, 1993; p. 159.

21. Merkhan, K.; Alkass, J.E. Influence of udder and teat size on milk yield in Black and Meriz goats. Res. Opin. Anim. Vet. Sci. 2011, 1, 601-605.

22. Izadifard, J.; Zamiri, M.J. Lactation performance of two Iranian fat-tailed sheep breeds. Small Rumin. Res. 1997, 24, 69-76. [CrossRef]

23. SAS. SAS; Version 9.3; Software; SAS Institute: Cary, NC, USA, 2010.

24. Tedeschi, L.O. Assessment of the adequacy of mathematical models. Agric. Syst. 2006, 89, 225-247. [CrossRef]

25. Cochran, W.G.; Cox, G.M. Experimental Design, 2nd ed.; WILEY: Hoboken, NJ, USA, 1992.

26. Loague, K.; Green, R.E. Statistical and graphical methods for evaluating solute transport models: Overview and application. J. Contam. Hydrol. 1991, 7, 51-73. [CrossRef]

27. Mayer, D.G.; Butler, D.G. Statistical validation. Ecol. Modell. 1993, 68, 21-32. [CrossRef]

28. Adegoke, E.O.; Machebe, N.S.; Ezekwe, A.G.; Agaviezor, O.B. Effect of parity on changes in udder traits, milk yield and composition of West African dwarf sheep during lactation. Anim. Prod. Sci. 2016, 57, 1047-1057. [CrossRef]

29. Ángeles Pérez-Cabal, P.; Legaz, E.; Cervantes, I.; de la Fuente, L.F.; Martínez, R.; Goyache, F.; Gutiérrez, J.P. Association between body and udder morphological traits and dairy performance in Spanish Assaf sheep. Arch. Anim. Breed. 2013, 56, 430-442. [CrossRef]

30. Sezenler, T.; Ceyhan, A.; Yüksel, M.A.; Önaldi, A.T.; Yildirir, M. Effect of parity and type of lambing on performance and udder traits of Bandirma ewes. Indian J. Anim. Sci. 2016, 86, 572-577.

31. Musaad, A.; Ayadi, M.; Khalil, A.; Aljumaah, R.S.; Faye, B. Change in Udder Measurements Traits during Lactation and Its Relationship with Milk Yield in Dairy Camel (Camelus Dromedaries). J. Agric. Vet. Sci. 2017, 10, 76-83.

32. Linzell, J.L. Measurement of udder volume in live goats as an index of mammary growth and function. J. Dairy Sci. 1966, 49, 307-311. [CrossRef]

33. Capote, J.; Argüello, A.; Castro, N.; López, J.L.; Caja, G. Short communication: Correlations between udder morphology, milk yield, and milking ability with different milking frequencies in dairy goats. J. Dairy Sci. 2006, 89, 2076-2079. [CrossRef] 
34. Akers, R.M. A 100-year review: Mammary development and lactation. J. Dairy Sci. 2017, 100, 10332-10352. [CrossRef]

35. Crump, R.E.; Cooper, S.; Smith, E.M.; Grant, C.; Green, L.E. Heritability of phenotypic udder traits to improve resilience to mastitis in Texel ewes. Animal 2019, 13, 1570-1575. [CrossRef]

36. Milerski, M.; Margetín, M.; Čapistrák, A.; Apolen, D.; Špánik, J.; Oravcová, M. Relationships between external and internal udder measurements and the linear scores for udder morphology traits in dairy sheep. Czech J. Anim. Sci. 2006, 51, 383-390. [CrossRef]

37. Haile, A.; Hilali, M.; Hassen, H.; Rekik, M.; Lobo, R.N.B.; Tibbo, M.; Mwacharo, J.M.; Rischkowsky, B. Evaluation of Awassi sheep genotypes for growth, milk production and milk composition. J. Exp. Biol. Agric. Sci. 2017, 5, S68-S75. [CrossRef]

38. Dhaoui, A.; Chniter, M.; Atigui, M.; Dbara, M.; Seddik, M.M.; Hammadi, M. Factors affecting the milk yield and composition over lactation of prolific D'man ewes in Tunisian oases. Trop. Anim. Health Prod. 2019, 51, 507-518. [CrossRef] [PubMed]

(C) 2020 by the authors. Licensee MDPI, Basel, Switzerland. This article is an open access article distributed under the terms and conditions of the Creative Commons Attribution (CC BY) license (http://creativecommons.org/licenses/by/4.0/). 